\title{
Integration of Knowledge (loK) Methodological Reasoning of Islamic Economics (IE) as the Wisdom of Humanity: A Heterodox Economic Approach
}

\author{
Jasmin Omercic \\ Unaffiliated PhD Graduate in Economics (IIUM), Bosnia and Herzegovina \\ Corresponding email: omercic_jasmin@hotmail.com
}

Article History

Abstract

The world increasingly needs an alternative approach to economic development. This paper endorses the Integration of Knowledge (IoK) approach as the wisdom of humanity through Islamic Economics (IE). A review of relevant literature through qualitative methodologies of library research, discourse and critical content analysis highlights the civilisational practices of integration, how development of economics diverged from such practices and how heterodox approaches reacted to such divergence. A section on learning the wisdom of humanity from each other emphasizes the inevitable historical civilizational integration (IoK) and exchange of knowledge. It follows with a literature review of the development of mainstream economics, how it abandoned such historical civilizational practice and its sound foundations, namely ontology, epistemology, axiology and methodology. A highlight of heterodox economics (HE) responses reveals the alternatives to the mainstream-focused positivistic approach to economics. The inadequacy of those alternatives led us to demonstrate Muslim responses and the centrality of IE as a comprehensive alternative heterodox economic approach. The analysis shows how IE grew along Islamisation of Knowledge (IOK) as two parallel and major intellectual ișlah (reform) and tajdid (renewal) movements. A brief review of the development of each shows the potential of IE's IoK methodological reasoning to revive the loK approach in economics as the wisdom of humanity. The sound IE philosophical foundations, namely ontology, epistemology, axiology and methodology, have a major impact in that process. Thus, utilising the core loK objective within IOK together with IE contributions shape the process of overcoming problems and issues of mainstream economics. Actionable recommendations to practitioners and academics depict how the IE approach to economics could be implemented and sustained along SDGs agenda.

Keywords: Heterodox, Islamic Economics, Integration of Knowledge (IoK) Methodology, Wisdom.

JEL Classification: B10, B41, B50, N01.

Type of Paper: Systematic Review

@ IJIEF 2021 published by Universitas Muhammadiyah Yogyakarta, Indonesia All rights reserved

DOI:

https://doi.org/10.18196/ijief.v4i2.11658
Web:

https://journal.umy.ac.id/index.php/ijief/article/view/11658

Citation:

Omercic, J. (2021). Integration of Knowledge (IOK) methodological reasoning of Islamic economics (IE) as the wisdom of humanity: A heterodox approach. International Journal of Islamic Economics and Finance (IJIEF), 4(2), 233-262. DOI: https://doi.org/10.18196/ijief.v4i2.11658 
Omercic| Integration of Knowledge (IoK) Methodological Reasoning of Islamic Economics (IE) as the Wisdom of Humanity: A Heterodox Economic Approach

\section{Introduction}

\subsection{Background}

The disparaging reality of economics with its frequent crises led to diverging perspectives of how the future of economics might look. Works like Omercic, Haneef and Mohammed (2020) highlighted the foundational problems of mainstream economics as an ontology limiting the nature of being to physical objects, an epistemology limited to reason and experience as sources/theory of knowledge, futility or marginalisation of axiology (ethics, morality) followed by a deficient methodology. This paper explores and shows in greater detail why the foundational problems of mainstream economics require an alternative. It starts by showing how the abandoned learning and integrating the wisdom of humanity from each other was the practice among civilisations. This is the motivation of our paper in further exploring how that evolved in economics. Economic interests were always central in decision making. While later paragraphs elaborate such learning practices from each other more generally and identify the papers' objectives, a subsequent literature review of the development of mainstream economics reveals how the discipline abandoned its historical foundations and wisdom and pursued a positivistic material approach to economic analysis. Then, an insight into heterodox economics (HE) responses to the hegemony of mainstream economics highlights commendable alternative approaches to economic analysis but most left problems of foundations unaddressed. These are gaps which promote IE as an alternative heterodox approach, considering Muslim responses through ișlah (reform) and tajdìd (renewal) movements. A thorough analysis of notable intellectual movements of Islamisation of Knowledge (IOK) and Islamic Economics (IE) as holistic heterodox responses to the materialist Western civilisational practice and worldview, and the problems of mainstream economics demonstrates the centrality of Integration of Knowledge (IOK) methodological reasoning of IE based on sound foundations and its potential to overcome problems of mainstream economics.

In order to understand the significance of such IE reasoning, we must delve into the greater meaning of learning from each other as the wisdom of humanity and relate it to economics.

\section{Learning from Each Other: The Wisdom of Humanity}

Each civilisation benefitted from the grand achievements of the other, and over years accumulated knowledge that benefits humanity today. Each civilisation had particular features and a context that gave it an advantage over the other in some respects, but the exchange of goods and knowledge benefited humanity as a whole (Nasr, 1996). Despite the existing rivalry 
Omercic| Integration of Knowledge (IoK) Methodological Reasoning of Islamic Economics (IE) as the Wisdom of Humanity: A Heterodox Economic Approach

between civilisations, the greater good and the inevitability of interaction between civilisations and the exchange of knowledge always accumulated new or integrated knowledge to benefit future generations. Learning from each other was continuous irrespective of human will (Nasr, 2006, 2006a). However, it is also incumbent to critically evaluate each civilisation's contribution. When the Qur'an was revealed, the Roman and Persian civilisations were rivals, yet each contributed to humanity. The Islamic civilisation adopted some contributions after critical analysis and adapted it to its philosophical foundations rooted in the Qur'an, Sunnah, ijma, qiyas, and others (Karčić, 1990; Çizakça, 2000). The Islamic civilisation enhanced and developed new knowledge (Saliba, 2007). Such enormous enrichment from the universal wisdom of humanity is necessary today to overcome problems of disciplines like mainstream economics. It justifies and motivates the approach of this paper and revives the loK methodological reasoning approach to civilizational and economic development particularly within IE as the wisdom of humanity. We, however, shall also utilise the excellent practices of mainstream or HE to benefit humanity.

However, learning and integrating the achievements of civilisations are easier said than done; it takes time, and could lead to conflicts (Nasr, 2006, Acikgenc, 2014). Samuel Huntington's portrayed this interaction and exchange or integration as "Clash of Civilisations" and mainstream economics emulated it so greatly (Said, 1979). But Karčić (1990) refuted Huntington's view by pointing out how civilisations learn from each other and cooperate, like during the times of the Islamic civilisation that interacted more peacefully than any civilisation with older civilisations. For centuries, it preserved, enhanced, and integrated the knowledge and wisdom of humanity based on sound foundations, namely ontology, epistemology, axiology, and methodology derived from the sources of knowledge in Islam (Haneef, 1997; Furqani, 2012; Omercic et al., 2020). We define it in this paper as IoK based on IOK for IE development. The foundations always involved an interplay of metaphysical and physical realms of which those of the former are central and the source of all knowledge, i.e. Qur'an - Allah's SWT revelation and Sunnah as its Prophetic exemplification, peace be upon him (PBUH). Such high respect for knowledge was never attained by any other civilisation according to Toynbee (1987) and Wain and Kamali (2018). It was the source of inspiration for the Western intellectual revival since medieval times through the enlightenment, reformation, scientific revolution, and others (Pribram, 1983). The scientific paradigm is particularly significant and became dominant since the mid-19 $19^{\text {th }}$ century (Kuhn, 2012), and since then, has benefitted humanity with its scientific wisdom. Integration occurred but took time and had its share of difficulties and tensions. 
Omercic| Integration of Knowledge (IoK) Methodological Reasoning of Islamic Economics (IE) as the Wisdom of Humanity: A Heterodox Economic Approach

However, Said's (1979) 'Orientalism' pioneered the depiction how the West misused science and moulded its revival through the selective use of the wisdom of the Islamic civilisation while discarding its philosophical foundations (Acikgenc, 2014; Bakar, 2019), ethics, and religious-spiritual teachings (Nasr, 2010). Those foundations, however, were the sources of divine guidance of all past civilisations. It ensured unity in diversity and vice versa, the multiplicity in diversity and vice versa, and unity leading to unity (Nasr, 2006; Wain \& Kamali, 2018). By abandoning such foundations, the Western discipline of economics became the leading force of poverty, inequality, and financial crises (Mirakhor, 2020).

According to Sardar and Henzell-Thomas (2017), and Mahomedy $(2016,2017)$, the Western rejection and Muslim failure to uphold its foundations besides other internal problems of the Islamic civilisation shows that the discourse on learning from each other is necessary to enhance the interaction, exchange, and knowledge integration in contemporary times. It is necessary to revive the loK methodological reasoning and clearly a rationale and motivation of this paper. Thus, we clarify the objectives of this paper in next section and continue with a literature review of the development of economics to understand the urgency of such loK as the wisdom of humanity in greater depth while also highlighting the problems of mainstream economics and why IE is a suitable alternative.

\subsection{Objective}

The earlier section identified the significance of the rationale and motivation of this paper to revive the practice of learning from each other as the wisdom of humanity generally and in economics particularly. We opt to conceptualise it as the 'loK methodological reasoning' in contemporary times. Hence, we can openly state that the main objectives of this paper are to review how development of economics abandoned such loK methodological reasoning and how the heterodox alternatives responded to it; and to analyse and demonstrate the potential of IE to revive such reasoning in development of economics. These objectives identify the importance of holistic and multidimensional approaches in addressing problems and issues of economics through IoK methodological reasoning of IE. It explains why IE is increasingly appraised in research as the alternative to orthodox economic reasoning. Moreover, such an IE offers a sound basis upon which problems of Islamic banking and finance can be resolved in light of certain maqașid. Simultaneously, we can plan concretely towards faster attainment of SDGs.

The following literature review addresses how development of economics diverged and ignored loK methodological reasoning as well as how heterodox 
Omercic| Integration of Knowledge (IoK) Methodological Reasoning of Islamic Economics (IE) as the Wisdom of Humanity: A Heterodox Economic Approach

approaches responded to the general course of orthodox economic reasoning. This identifies gaps that the paper aims to fill through an extensive analysis of mutual benefit and potential of IoK methodological reasoning within IOK and IE responses to orthodox economic reasoning. However, a methodology section of this paper precedes the analysis and results or findings section. Lastly, we extrapolate how such an IE development with an loK methodological reasoning boosts development of Islamic banking and finance and eases attainment of SDGs. We conclude and provide actionable recommendations for practitioners, academics and further research.

\section{Literature Review}

The following brief review on the development of economics eases comprehension how economists ignored loK methodological reasoning in problem solving or decision making. Such a contrast to the Muslim civilisational practice and their own tradition is a gap which popularises alternative (heterodox) economic reasoning. It gained momentum with frequent crises in orthodox economic reasoning, yet inadequacy of western heterodox responses becomes apparent with the IoK approach to IE development in this paper based on IOK. We then analyse these thoroughly and present results in the final section of this paper.

\subsection{Development of Economics}

Economics was always part of human life and developed as a modern discipline since the $16^{\text {th }}$ century enlightenment in the West according to Pribram (1983). For the Western civilisation, its roots stem from Greek and Roman philosophy and ignore the contributions of the Islamic civilisation to multidisciplinary development and thought like economics from the $7^{\text {th }}$ century until its gradual weakening during the $17^{\text {th }}$ century in view of Malkawi, (2014) and Saliba (2007). However, this does not mean that the intellectual activity of the Muslims did not continue past the $17^{\text {th }}$ century (Nasr, 2006a). Economics or iqtisad developed as an integral part of Islam, as a way of life, reflective in idarah or administration, waqf or endowment, zakah, or almsgiving, sadaqah or charity and foremost the trading in the market of Madinah (Chapra, 2001, 2016; Çizakça, 1998). Interaction, integration and exchange of knowledge and wisdom of humanity with the Greek and Roman heritage was a common practice of the Islamic civilisation as noted by Koehler (2014) and Saliba (2007). 
Omercic| Integration of Knowledge (IoK) Methodological Reasoning of Islamic Economics (IE) as the Wisdom of Humanity: A Heterodox Economic Approach

In the Islamic civilisation, Bakar (2019) showed that Imam Al-Ghazali (1058$1111 \mathrm{AC}$ ) classified 'sciences of transactions (mu'amalat)', comprising economics, under the sub-category of the sciences of branches (furu') or derived principles of the category of religious sciences (u'lum shar'iyyah). AlGhazali perceived economics as a religious obligation under the fard al-kifayah (collective obligations), the category that needs to be studied as a person's obligation to society. More than a century after Al-Ghazali, Qutb AI-Din Shirazi (1236-1311AC) categorised 'economics' under the practical philosophical sciences (u'lum hikmiyy). All the above implies that economics requires robust philosophical foundations, namely ontology, epistemology, axiology, and methodology, derived from the sources of knowledge in Islam as elaborated by Haneef (1997) and Furqani (2012). Thus, an loK methodological reasoning prevailed during those times in practice and theory like Islamic law, politics and even economics.

However, modern Western mainstream economics stopped interaction, integration or loK methodological reasoning, exchange and learning from the wisdom of humanity. The West was convinced it has superior knowledge with the rise of positivism and the scientific revolution that brought about prosperity, but its ineffectiveness and inherent economic instability proved otherwise according to Mahomedy (2016), Chapra (2016) and Omercic et al. (2020). It became obvious to many scholars that mainstream economics suffers from inherent foundational problems that exacerbate its crisis (Stiglitz, 2019; Mirakhor, 2020). In view of Omercic et al. (2020), it suffered due to the missing loK methodological reasoning in economics. The next sections shall depict such a crisis in greater detail.

\subsubsection{The Multidisciplinary, Ethical and Moral Approach to Economics Before Dichotomisation}

Thoughts and apprehensions about economics were always treated in a crossand interdisciplinary fashion as Ibn Khaldun (1332-1406) elaborated in his magnum opus 'Muqaddimah (Introduction)' as noted by Weiss (1995) and Alatas (2014). Scholars like Ibn Khaldun adopted a broad ontology, epistemology, axiology, and methodology that fostered multi-disciplinarity with reference to the physical and metaphysical worlds according to Alatas (2014) and Acikgenc (2014). This is what we earlier conceptualised the loK methodological reasoning based on IOK. Ghazanfar (2003) perceived that such was also the reasoning and writings of Greek and Roman philosophers, later scholastics (13 ${ }^{\text {th }}$ century) like Thomas Aquinas (d.1274) and Albertus Magnus (d.1280), and the early Western enlightenment scholars. It is the collective wisdom of humanity. 
Omercic| Integration of Knowledge (IoK) Methodological Reasoning of Islamic Economics (IE) as the Wisdom of Humanity: A Heterodox Economic Approach

To develop economics, the West rejected the Islamic philosophical foundations because of the belief in the supremacy of Christian teachings of morality and ethics but Pribram (1983) and Schumpeter (1954) showed that the West failed to uphold even its own teachings. Moreover, contemporary research depicted the Schumpeterian gap in Western economics (Samuels, Biddle, \& Davis, J. B, 2008) as the age of intellectual flourishing of the Islamic civilisation that inspired Western economic and other thought. Hence, Haneef $(2014,2005)$ called for a multidisciplinary and pluralistic methodological approach to discipline development as Islam promoted which the West abandoned without justification. Saliba (2007) showed that marginalisation of morality, ethics or religion is result of secularisation and reflects a paradox and cognitive dissonance of mainstream economic thought and contrasts findings of Islahi (2005, 2014), Mirakhor (2020), Omercic et al. (2020), to name a few. The physicalist ontology, rationalist epistemology, futile axiology, and deficient methodology problems of mainstream economics are results of such neutralisation. Thus, this paper depicts IE development through the IoK methodological approach (based on IOK) as the solution.

The $16^{\text {th }}$ century enlightenment, reformation, and renaissance thinkers' development of a purely secular and rationalist approach to economics, moulding it along the line of physics, mathematics, or Newtonian science, according to Zaman $(2010,2013)$, failed to realise that Newton was highly religious in view of Saliba (2007). Even Weber's (2002) claim of the superiority and salvation via the Protestant ethic in relation to a purely secular approach to economics led to the evolution of the spirit of capitalism and secularisation in the name of science. This scientific shift intensified in the middle of the $19^{\text {th }}$ century and stripped away normative aspects or theological ratiocination in Western economics (Kuhn, 2012). The West then nurtured such positivist, mechanistic, material, dry, causality, and greed-based self-centric economic thought according to Hunt (2016).

Thus, the focus on scientific and rejection of metaphysical reasoning in economics is a root cause of mainstream economics' instability, indebtedness, income inequality, and poverty. Scholars like Omercic et al. (2020), Mahomedy (2016, 2017), and Furqani (2012) showed that those issues result from the flawed philosophical foundations of mainstream economics and suggested IE as an alternative that we appraise via loK methodological reasoning in this paper as the revival of the wisdom of humanity.

\subsubsection{Dichotomisation of Economics}

Thus, in the course of the eighteenth century, economics was transformed from a moral discipline into science the propositions of which were derived 
Omercic| Integration of Knowledge (IoK) Methodological Reasoning of Islamic Economics (IE) as the Wisdom of Humanity: A Heterodox Economic Approach

from a few abstract premises and were largely free from normative connotations. (Pribram, 1983, p. xlix)

The initial dichotomisation of economics into positive and normative during the $18^{\text {th }}$ century led to dominance of positivistic economics from the mid-19 $9^{\text {th }}$ century according to Hunt (2016). While some say that positive economics started with the writings of Adam Smith (Heilbroner \& Milberg, 1995), his thought was infused with morality and ethics yet stratified from his theory of moral sentiments with roots to the $13^{\text {th }}$ century and the Islamic influence from the $7^{\text {th }}$ to $13^{\text {th }}$ centuries in view of Arif $(1985,1987)$. Thus, normative economics guided and worked together with positive economics within sound philosophical foundations that we need to revive as part of the wisdom of humanity or lok methodological reasoning and integrate beneficial modern economic and other knowledge. However, the West gave positive economics unique precedence.

Argyrous and Stilwell (2011), Putnam and Walsh (2012) and others tried to reappraise the role of normative economics but the scientific paradigm persevered. According to Screpanti and Zamagni (2005), most classical economists supported the scientific paradigm in the quest for preciseness in economic like in physics and mathematics. However, Putnam and Walsh (2012) revealed that it was just scientifically probable and fallible in relation to scientific postulates. Thus, it needs a more dynamic approach with sound philosophical foundations as proposed by Furqani $(2012,2015,2017)$ and Omercic et al. (2020).

\subsubsection{From Classical and Keynesian to Neo- and Post-Types of Economics}

With the breakthrough of Keynesian economic thought during the Great Depression began the rivalry between multiple streams and schools of economics (Froyen, 1996, 2009; Lee \& Lavoie, 2013). Constant issues like high US inflation and unemployment contradicted macroeconomic theory defined as the Philips curve and led to different schools of economics including heterodoxies (Lee \& Lavoie, 2013). For instance, Froyen (2009) claimed that Monetarism is supposed to curb inflation with the periodical supply of money to ensure sufficient supply, but prolonged periods of high inflation and rising debt levels led to post-Keynesian economic thought (left and right Keynesians). Post-, neo- or other types of economics provided no solution to such issues which increasingly challenged mainstream economics in view of Keen (2011). Issues of rising income inequalities, uncontrolled inflation, rising debts and mortgages, poverty, unemployment, environmental degradation, climate change, and others inflated the issues and problems with mainstream economics during the $20^{\text {th }}$ and $21^{\text {st }}$ centuries (Stiglitz, 2019; Mirakhor, 2020). 
Omercic| Integration of Knowledge (IoK) Methodological Reasoning of Islamic Economics (IE) as the Wisdom of Humanity: A Heterodox Economic Approach

The 2008 Recession reflected the continuity of the instability and failure of mainstream economics that led Piketty (2014) and Chapra (2016), to name a few, to express the need to change the approach and explore alternatives like IE to the existing economic narrative, analysis, and development for greater genuine and universal social welfare (Omercic et al., 2020). The critique of mainstream economics' flawed foundations (Mahomedy, 2016, 2017), emphasis on its irrational exuberance (Shiller, 2015) and indication of its cognitive dissonance (Ayub, 2009; Irfan, 2015) renders the mainstream economics approach the root cause of many human problems. According to Ormerod et al. (1997), Keynes's words 'No one has the gospel' and apparent paradoxes show the need for a greater moral and ethical approach to developing economics (Putnam \& Walsh, 2012; Furqani, 2012, 2015, 2017). This requires reviving of loK methodological reasoning as the wisdom of humanity to develop IE and resolve issues of mainstream economics.

\subsubsection{The Need for Normative Economic Alternatives}

The greater marginalisation of normative economics (norms, ethics, morality, beliefs, religion) since the $20^{\text {th }}$ century proved detrimental within the everincreasing nihilistic economic order in view of Boland (2003) and Mirakhor (2020). The progressive rise of inequalities and other economic issues led to the demand for more ethical and moral responsibility and this signals the 'death' of economics as science according to Lee and Lavoie (2013), Stiglitz (2010) and Putnam and Walsh (2012), to name a few. According to Stiglitz (2019), economics is a progressing science, meaning that pure science-based economic approaches are wrong. This justifies our appraisal and review of IE with its loK methodological reasoning as a distinct heterodox approach to overcome problems of mainstream economics. Insight into heterodox economic alternatives to the mainstream clarifies even more why the IE approach is most suitable.

\subsubsection{Heterodox Economics (HE) as Alternatives to the Mainstream}

\subsubsection{Heterodox Alternatives Before the Greater ' $\mathrm{HE}$ ' Block}

This review of $\mathrm{HE}$ as alternatives to mainstream orthodox economics highlights the heterodox alternatives as they existed before the formation of a greater block of 'HE' according to Lee and Lavoie (2013). Several economic ideas other than mainstream economics existed by end of the $19^{\text {th }}$ century and throughout the $20^{\text {th }}$ century. In Carson, Thomas and Hecht (2005) and Oatley (2015), we find categories of conservative, liberal, and radical. Frieden and Lake (2000) explained that the conservative alternative drew ideas from Adam Smith 
Omercic| Integration of Knowledge (IoK) Methodological Reasoning of Islamic Economics (IE) as the Wisdom of Humanity: A Heterodox Economic Approach

(1732-1790) and preferred a mercantilist style of economics with features of a more closed economic system, monopoly rights, and trade restrictions imposed by governments. The liberal alternative called for economic liberalisation, labour unions, welfare and 'big government'. To this end, Franklin Roosevelt envisioned a more balanced political economy (Oatley, 2015, Carson et al., 2005). Liberals mainly referred to the thought of John Maynard Keynes (1883-1946AC) and their role becomes important in the later development of HE with greater emphasis on general social welfare according to Hunt (2016) and Lee and Lavoie (2013). Liberals are also institutionalists like John Kenneth Galbraith and Robert Heilbroner. Lastly, the radical alternative is always associated with Karl Marx. It is very popular in academia due to a general critique of capitalism, its nature, etc. (Heilbroner \& Milberg, 1995; Carson et al., 2005). Sadr (1987, 1982 Vol.1\&2-Part1\&2, 2016) systematically reviewed Marxist economic thought and highlighted its significant critique of mainstream economics' ontological, epistemological, axiological and methodological foundations. Sadr showed how it did not provide a better alternative to such foundations and appraised IE as a solution.

\subsubsection{2. $\mathrm{HE}$}

' $H E^{\prime}$ existed as early as the 1870s after the neoclassical revolution along with socialist critique of mainstream capitalism. These included advocates of various economic schools (i.e. historical school, forms of mercantilism) of which some were adherents of conservative, liberal and radical economic thought (i.e. Marxists, institutionalists) according to Lee (2009, 2011). Today, 'HE' comprises a pool of economic traditions, i.e. Austrian, feminist, green, institutionalist, Marxian, post-Keynesian, radical, Sraffian, social and other newer, existing or older traditions of economics (Association of Heterodox Economics, 2020; Power, 2012). Heterodox economic thought challenges the irrational exuberance of mainstream economics (Shiller, 2015), detachment from reality, theoretical and mathematical abstractness, etc. and joined $\mathrm{HE}$ in view of Keen (2011) and is hard to define. Nevertheless, the 2003 International Confederation of Associations for Pluralism in Economics (ICAPE) defined its mission to promote pluralism in economics. According to Davis (2008), ICAPE helped to identify three specific commitments of $\mathrm{HE}$, namely (1) rejection of the atomistic individual conception in favour of a socially embedded individual conception; (2) emphasis on time as an irreversible historical process; and (3) reasoning in terms of mutual influences between individuals and social structures. These, however, do not distinguish whether an economic tradition is orthodox or heterodox. Thus, Davis (2008), Lee (2009) and others stated that a tradition is heterodox if it (1) failed to become orthodox following a period of pluralism; (2) lost the status of orthodox when a new orthodoxy emerged; (3) fails to redirect orthodoxy from outside orthodoxy; and (4) fails to redirect 
Omercic| Integration of Knowledge (IoK) Methodological Reasoning of Islamic Economics (IE) as the Wisdom of Humanity: A Heterodox Economic Approach

orthodoxy from inside orthodoxy. For example, post-Keynesianism became part of HE in 2010 after eminent post-Keynesian economist Marc Lavoie and eminent heterodox economist Fred Lee realised that their critique of mainstream economics had much in common. Similarly, the post-autistic economics network (PAECON) that started in 2000 became part of HE because of a thorough drive to review the general curriculum of mainstream economics through an international open letter (Post-Autistic Economics Network, 2020). PAECON focused more on behavioural aspects, cultural and historical heritage and context, including new empirical theories and methods, and a multidisciplinary approach to economics in view of Fullbrook (2002).

Because of the heterogeneity of $\mathrm{HE}$, traditions overlapped in the critique of mainstream economics and share an emphasis on issues of justice, social relationships in terms of class, gender, and race, the wealth of nations, full employment, economic and social reproduction and accumulation (Power, 2012). Lee (2009) summed up these shared concerns through a definition of economics as "the science of the social provisioning process" (p.8) while examining "how capitalism works" (p.9). Greater social welfare is a commendable heterodox position while not rejecting the contributions of mainstream economics. However, it is inevitable to notice how most, if not all, $\mathrm{HE}$ traditions have no clear stance towards the role of religion or metaphysics within historically relevant philosophical foundations (ontology, epistemology, axiology, methodology) of economics as reviewed earlier. Nasr (2006) and Hunt (2016) claimed that there is a phobia, reluctance, or lack of will to include religion into the discourse of life and economics particularly. Thus, HE requires sound foundations that cannot be compromised while maintaining a heterogeneous approach to economic analysis. This paper's IE development via the IoK approach based on IOK is a more worthwhile and holistic heterodox alternative because it welcomes all good contributions of orthodox and $\mathrm{HE}$ and is open for common religious perspectives and dialogue that do not contradict foundational Islamic teachings. A thorough analysis reveals more after the methodology section.

\section{Methodology}

Before the results and analysis of the diversified Muslim responses to earlier reviewed development of economics, we specify the methods used in this paper's qualitative methodological approach. Ritchie and Lewis (2003) perceived the results of such approaches thorough and reliable due to the demonstrative logic. Methods like extant literary review, discourse and critical content analysis facilitate such a narrative in this paper. It is understandable to everyone and provides alternative perceptions of phenomena in view of 
Omercic| Integration of Knowledge (IoK) Methodological Reasoning of Islamic Economics (IE) as the Wisdom of Humanity: A Heterodox Economic Approach

Denzin and Lincoln (2008). Moreover, these methods enable the researcher to extract holistic affirmative yet objective arguments which help to answer respective research objectives.

Moreover, the distinct nature of this paper's subject matter compelled us to pursue a non-standardised methodology or methodological pluralism. Concretisation (from general to particular and vice versa), comparative, and methods of logic (i.e. induction, deduction, synthesis) complement the method of critical content analysis and extant library research in this paper. According to Hadzic (2005) and Omercic et al. (2020), this is a mandatory approach due to the unique sources of knowledge of IE and IOK, i.e Qur'an as Revelation, Sunnah as Prophetic PBUH heritage, figh and usul al-figh. Moreover, their inherent loK methodological reasoning approach is another reason why methodological pluralism is mandatory and better. It ensures coherence of the contemporary with the traditional reasoning during the era of Islamic civilisation. The objective to revive such traditional reasoning as the learning from each other the wisdom of humanity or loK methodological reasoning renders the methodological approach of this paper credible and reliable. Hence, this methodology is becoming the basis upon which future studies can contribute further.

\section{Results and Analysis}

\subsection{Muslim Responses: Islah and Tajdid, the IOK Movement and Islamic Economics}

This section reviews, in brief, some religious, political, and intellectual iș/ah and tajdid (reform and renewal) movements as responses to Western thought and economics particularly that started after the death of the Prophet peace be upon him (PBUH) in the $7^{\text {th }}$ century. Those seek to reinstate genuine affairs in compliance with Islamic teachings integral of universal wisdom of humanity. We identify IOK and IE are two particular responses and analyse them in greater detail. This enables us to further link IE with HE as a unique approach through IoK based on IOK. The following discussion is particularly related to Muslims yet appeals universally to humanity.

\subsubsection{Islah and Tajdīd: Religious, Political/Economic and Intellectual}

Every reformist and renewal movement is by default religious as they aim to revive pristine Islamic teachings. Kamali $(2008,2013)$ found that Shihab alZuhri (d. 124AH/724CE) recorded tajdid to mean revival (ihya') of dying 
Omercic| Integration of Knowledge (IoK) Methodological Reasoning of Islamic Economics (IE) as the Wisdom of Humanity: A Heterodox Economic Approach

traditions while Al-Suyuti (d. 911/1505) ${ }^{1}$ explained it as the reestablishment of truth on earth, in society through the elimination of maleficent innovation (bid'ah), extremism (ghuluww), and the abhorred considering Islamic foundational teachings. This leads to the attainment of the objectives/maqasid of Shari'ah to benefit people, preserve their traditions, and good norms and practices of all civilisations (Voll, 1983). Hence, the religious nature of the movements is not purely for the revival and reform of ritualistic practices but is integrative and dynamic in reviving and reforming general social affairs and reinstating the wisdom of humanity (Al-Attas, 2014). Enayat (2005) claimed that there are religious movements that focus on preaching Islam ( $\left.d a^{\prime} w a h\right)$ yet this also improves the general welfare and peace of society. Political/economic reform and renewal movements aimed to revive Islamic teachings through political activism that involved economics (Enayat, 2005). This, however, did not make them non-religious because Islam by definition is a way of life and not pure theology. Political/economic movements are best represented by Shah Wali Allah Dihlawi (d. 1762), Jamal al-Din al-Afghani (1838-1897), Muhammad 'Abduh (1849-1905), Rashid Rida (1865-1935), H. Hassan al-Banna (1906-1949), Abul A'la Mawdudi (1903-1979) etc. with varying intensity (Crone, 2014; Kamali, 2008, 2013; Shamsul, 1997; Karčić, 1990). The dissemination of pamphlets, newspapers, and books made these movements even intellectual-educational.

The intellectual movements are most significant to the problems with mainstream economics. Intellectual movements are more effective and carry the potential to revive the knowledge tradition of the Islamic civilisation in contemporary times (Abu Sulayman, 2016; Nasr, 2006) and so the loK methodological reasoning as the learning from each other the wisdom of humanity approach. The following is a review of some Muslim intellectual movements along IOK and IE which we characterised as the holistic heterodox economic approach with potential to overcome problems with mainstream economics through reviving the loK methodological reasoning.

Traditionalism or perennialism is an intellectual movement of a group of intellectuals like Rene Guenon (Abd al-Wāḥid Yaḥyá), Frithjof Schuon (Īsā Nūr al-Dīn), Martin Lings (Abū Bakr Sirāj ad-Dīn), Syed Hossain Nasr, Houston Smith, Jean Borella, etc. who believe in the transcendent nature of religions, the existence of primordial and universal truths and perennial wisdom or philosophy (Borella, 1992; Schuon, 2005; Nasr, 2010). While the thought of these intellectuals is rich and meaningful, it is very philosophical and complex and relatable to Sufism (Islamic esotericism) which makes it unidimensional whilst reflecting a higher degree of epistemological nature. It is, however, complementary to the IE development appraisal in this paper.

\footnotetext{
${ }^{1}$ Abu al-Fadl Abdu al-Raḥman ibn Abi Bakr ibn Muhammad Jalal al-Din al-Khudayri al-Suyuti.
} 
Omercic| Integration of Knowledge (IoK) Methodological Reasoning of Islamic Economics (IE) as the Wisdom of Humanity: A Heterodox Economic Approach

The ljmalis or futurists intellectual movement was founded by Ziauddin Sardar with other proponents like Munawar Ahmed Anees, Merryl Wyn Davies, S. Parvez Manzoor, etc. This movement addressed the problem of Muslim misconceptions and compromising the role and place of science in Islamisation writings. Thus, we may say that Sardar's (1989) critique of IOK resulted in his alternative of ijmalis that linguistically means comprehensive. Sardar's thought as an ijmali aimed to foresee a comprehensive future or plan for the future that considers universal Islamic teachings in contrast to the Muslim obsession, of which some Islamisation proponents are fixated on glorifying the past. However, Haneef's (2014) survey of Islamisation showed that the proper understanding of IOK clarifies no anti-science attitude but carefully integrates the use of science in the process of Islamisation. Later Sardar's and HenzellThomas's (2017) emphasis on the shift from Islamisation (IOK) to Integration of Knowledge (IoK) corroborates that even further. Hence, this paper's focus on reviving loK methodological reasoning as the learning from each other and the wisdom of humanity is timely and facilitates IE development as a holistic heterodox economic approach.

Islamic science as an intellectual movement developed in response to Western scientific development to show the historical existence of an Islamic scientific tradition that sparked the Western scientific revolution (Saliba, 2007; Acikgenc, 2014). Bakar $(1991,1999)$ showed a systematic symbiotic account of tawhid and the philosophy of Islamic science. Ziauddin Sardar and Syed Hossein Nasr are other prominent contributors to the discourse on Islamic science. Their contributions affirmed the compatibility of Islam and science and the potential of scientific development rooted in Islamic foundations (Sardar, 1989). This reasoning complements our approach in this paper to develop IE.

Individual ișlah and tajdìd intellectual movements were more frequent in early centuries of Islam and are rarer today. Among those who exist today are Yusuf Qardawi in the Muslim world, Tariq Ramadan and Abdul Hakim Murad (Timothy Winters) in Europe, Syed Hossein Nasr and Hamza Yusuf Hanson in the USA (Mohamad, 2016; Nasr, 2010). While not being actual movements, the impact is far greater than many movements historically. For instance, more than half a century of intellectual effort of Yusuf Qardawi revived and reformed many religious, social, political, economic, and other affairs. Similarly, the efforts of Ramadan, Abdul Hakim, Nasr, and Hamza transformed perceptions about Islam globally (Mohamad, 2016; Kamali, 2013; Kashani, 2014). Collectively, these individual movements fit into the general discourse of IOK and this paper's emphasis on reviving loK methodological reasoning within and through IE. IE, however, shall integrate within its body of knowledge beneficial contributions of mainstream or HE. Therefore, no absolute rejection of extant bodies of economic knowledge is acceptable and 
Omercic| Integration of Knowledge (IoK) Methodological Reasoning of Islamic Economics (IE) as the Wisdom of Humanity: A Heterodox Economic Approach

possible. Following sections shed more detail on the IOK and IE and reveal the potential to revive the loK methodological reasoning in contemporary times and show the way towards developing economics on genuine foundations. Thus, the reviewed ișlah and tajdid intellectual movements complement IE development through IoK and IOK by facilitating critical analysis of extant bodies of knowledge of conventional or heterodox nature, ie. HE. Hereby, we relevantise IE development through loK as a holistic HE approach based upon IOK. It also represents a major contribution as an imaginary framework upon which sound thought can explain the reality of the world and economic phenomena particularly. Such explanation, in view of Al-Attas (2014) would reflect the real and complete haqq (truth) and haqiqah (reality).

\subsection{Islamisation of Knowledge (IOK)}

Islamisation of Knowledge (IOK) is a unique intellectual movement based on sound philosophical foundations derived from sources of knowledge in Islam (Furqani, 2012; Omercic, 2018; Omercic et al., 2020). However, it is primarily a methodological movement with sound ontology, epistemology and axiology (Haneef, 2014). According to Abu Sulayman (1989), Wan Daud (1998, 2010) and many others, IOK is traceable to the times of Prophet Muhammad PBUH but started in the $20^{\text {th }}$ century with the writings of Syed Muhammad Naquib Al-Attas and Isma'il Raji Faruqi in the 1970s and 1980s, respectively. Interestingly, the writings of Syed Hossein Nasr in the 1960s also talked about the idea of IOK (Wan Daud, 1998). While Al-Attas presented IOK in a holistic (philosophical, rational, practical, Sufi etc.) perspective, Faruqi had a more rational and practical perspective according to Wan Daud $(1998,2010)$. Their unique styles of thought on IOK led to the establishment of the International Institute of Islamic Thought and Civilisation (ISTAC) in Malaysia, attached to AlAttas, and the International Institute of Islamic Thought (IIIT) in the USA, attached to Faruqi. The former was purely educational while the latter was a non-governmental organisation (NGO), a private, non-profit, academic, cultural, and educational institution (IIIT, 2020a; Haneef, 2014). ${ }^{2}$ The IOK practice within both institutions was complementary despite unique features and focus of each because of the distinct thinking styles of its founders (Hashim \& Rossidy, 2000).

The major objective of IOK remained the interaction between the Islamic and other legacies (turath) with modern bodies of knowledge (Al-Attas, 1978, 1980; Al-Faruqi, 1982). It remained concerned with achieving this aim and few attempted to develop a methodology to attain this objective, what led to

\footnotetext{
${ }^{2}$ IIIT advanced the establishment of International Islamic University Malaysia (IIUM) of which ISTAC became a branch, International Islamic University of Islamabad (IIUI), and others.
} 
Omercic| Integration of Knowledge (IoK) Methodological Reasoning of Islamic Economics (IE) as the Wisdom of Humanity: A Heterodox Economic Approach

greater thought on epistemological integration and foundations (Furqani, 2012; Furqani \& Haneef, 2012; Malkawi, 2014; Omercic, 2021).

Further development of IOK or attaining the defined vision failed primarily because of a failure to understand or poor understanding and communication of what IOK really entails (Omercic, 2021; Haneef, 2014; Al-Attas, 1978). That caused significant critique, most of which were constructive revisions of initial IOK frameworks according to Abu Sulayman (1989) and Safi (1993). IOK remained deeply concerned with questions of ontology, epistemology, ethics, and morality (axiology) (Malkawi, 2014). IOK methodology is the least developed of all foundations despite extensive writings on this topic (Safi, 1993). However, the sound foundations render IOK a genuine and relevant methodological basis to develop disciplines like IE, a holistic HE approach, to address problems with mainstream economics. This gap is overcome with adoption of the contemporary methodological shift within IOK to loK that Malkawi's (2014) 'Epistemological Integration' made obvious. Aggregatively, it revives the loK methodological reasoning as wisdom of humanity for IE development as an alternative and holistic HE.

Even Crow (2018) and Sardar and Henzell-Thomas (2017) emphasised the need for more integration instead of Islamisation while Malkawi (2014) and Haneef (2014) explicitly expressed still the need for both with, however, a greater focus on integration efforts to develop contemporary bodies of knowledge. A methodological focus in the past IOK contributions and the shift to loK methodological reasoning today just reflects its real foundational teachings in practice which this paper depicts as the solution to problems of mainstream economics. Its ontology and epistemology that recognizes metaphysical besides physical phenomena and sources of knowledge, and axiology derived from akhlaq/ethics of the sources of knowledge in Islam (Haneef, 1997) are facts indicating greater contextual adaptability, understanding and explanation of reality (haqiqah). The outcome of such reasoning is truth (haqq) or real economics. Thus, IOK is an advanced intellectual movement among alternative Muslim responses to western general and economic reasoning because none had as much impact and received as much attention and thought. An additional indicator of IOK as a significant intellectual alternative to problems with mainstream economics in contrast to other Muslim and Western responses is many books and journal ${ }^{3}$ publications and translations at the headquarter and regional offices of IIIT (IIIT, 2020; Haneef, 2014). Therefore, IOK is the basis of the loK methodological reasoning to learn from each other the wisdom of humanity. IIIT adopted this approach in the $21^{\text {st }}$ century more ardently. This corroborates our appraisal of

\footnotetext{
${ }^{3}$ Such as 'Intellectual Discourse' journal of International Islamic University Malaysia (IIUM), 'Al-Shajarah' journal of ISTAC-IIUM, 'Muslim Education Quarterly' of Cambridge University, 'American Journal of Islamic Social Science (AJISS) ' of IIIT, 'Journal of Islamic Science' of Association of Muslim Social Scientists (AMSS), etc.
} 
Omercic| Integration of Knowledge (IoK) Methodological Reasoning of Islamic Economics (IE) as the Wisdom of Humanity: A Heterodox Economic Approach

IE development through IOK as a holistic HE approach in this paper to overcome problems of mainstream economics. It is a universal approach of interaction between legacy/classical and modern knowledge as a human accumulated legacy knowledge until today. The greater analysis of the application of such an approach to IE in the following section makes it obvious.

\subsection{Islamic Economics (IE)}

The intellectual movement of Islamic Economics (IE) in the form of discourse and writings predates that of IOK from the late $19^{\text {th }}$ and early $20^{\text {th }}$ centuries (Islahi, 2010). According to Chapra (2016), IE development led to greater Muslim discourse on economics from an Islamic standpoint in a contemporary context as was the case throughout the Islamic civilisation whereby economics was an integral part of the religious science (ulum al-shari'iyyah) discourse and integrated within the idarah (general administrative management) of daily affairs (Bakar, 2019). The literature review of this paper showed in detail how Muslim polymaths like Imam al-Ghazali classified economics as a religious obligation to some people (fard al-kifayah). Thus, economics was a daily occupation of Muslims' living of Islam as a way of life and not purely ritualistic experience.

Likewise, economics occupied a central role within the Western civilisation as clear in colonial and imperial times (Hunt, 2016). Because of the centrality of interest or riba in Western economic reasoning, it became a major concern of the IE discourse (Siddiqi, 1983, 2004, 2004a). Hence, the idea was to develop an interest-free economic system. This characterised the preparatory period of IE from the middle of the $19^{\text {th }}$ to early $20^{\text {th }}$ century when much of Western economic thought was translated into the different languages of Muslim communities (Islahi, 2010). ${ }^{4}$

We mentioned earlier that the reviewed intellectual movements complement the development of IE (Enayat, 2005). An important feature of the scholars of this period was their multidisciplinary approach that characterises the nature of IE or its basis on IOK and current appraisal via loK methodological reasoning. In view of Islahi (2010), the first-generation of 1926-1950 were the real founders of $I E^{5}$ and defined it with an emphasis on the distinction from mainstream economics that underwent major clashes between classical, Keynesian, and other streams of thought. Apparent is how IE with its IoK

\footnotetext{
${ }^{4}$ More prominent scholars of this period were: A'bd al-Qadir al-Mijawi and U'mar Burayhimat from Algeria; Muhammad A'bduh and Rashid Riḍa from Egypt; and Shibli Nu'mani, Muhammad Iqbal, Sayyid Sulaiman Nadwi and Abus-Salam Nadwi from the Indian sub-continent.

${ }^{5}$ IE scholars of this period were: Hifzur Raḥman Sewharawi, Manazir Aḥsan Guilani, Abul A'la Mawdudi, Muḥammad Hamidullah, Anwar Iqbal Quraishi, Shaikh Mạ̣mud Aḥmad, Yusufuddin, Zaki Șaliḥ, Muḥammad A‘li Nasha`t, Ahmmad Muhammad Rị̣wan, Abu Zaharah. A‘li Fahmi Taman, Muhammad A‘bdullah al-A‘rabi, etc..
} 
Omercic| Integration of Knowledge (IoK) Methodological Reasoning of Islamic Economics (IE) as the Wisdom of Humanity: A Heterodox Economic Approach

methodological reasoning represents a serious intellectual alternative to mainstream economics mainly because of inherent inconsistency and flawed foundations (Siddiqi, 1981, 1983).

The 'big push' of IE distinguishes the second-generation from 1951-1975, known as the pioneers of IE ${ }^{6}$, who according to Islahi (2010) and Siddiqi (1981) gave impetus to the development of Islamic banking and finance (IBF). According to Kahf $(1989,1998)$, the international conferences on Islamic Economics in 1976 and later events played a major role in that. Scholars of this period had traditional and modern education in economics (Haneef, 1995, 2014). Their efforts reflect the inevitability of integration between the two and corroborate this paper's rationale for IOK based IE development through the loK methodological reasoning as the revived learning from each other and wisdom of humanity approach. IBF, like mainstream economics, diverged from such loK methodological reasoning and fell prey to replicating mainstream banking and finance practice (Omercic, 2018, 2021). Thus, some guidance and convergence through the loK methodological reasoning is necessary and possible. The IE generation ${ }^{7}$ of $1976-2000$ fostered development via more conferences and the rise of journals in IE that makes this intellectual movement a very distinct one compared to earlier Muslim responses to the West and economics (Islahi, 2010; Chapra, 1996, 2001). Greater non-Muslim interest during this period was apparent according to El-Ashker and Wilson (2006). However, later generations of IE from the 2000s until today witnessed a stagnation and abstractness of thought in IE while IBF characteristically continued to track the development of mainstream economics via replication and attempts of product differentiation (Khan, 2013, 2013a). Irfan (2015) showed that IBF, like mainstream economics, suffers from foundational problems that also represent a gap to overcome with this paper's appraised IE development as a holistic HE approach through loK methodological reasoning based on IOK. Hence, this is a major contribution to what the contemporary IE generation could pay further attention. This approach establishes the relevance of IOK for IE development, revives interest in them and demonstrates the potential of IE to not only overcome problems of mainstream economics and link IBF to its initially defined philosophical foundations, but also to expedite attainment of SDGs through a focus on maqașid. The maqașid theory is also central to IE and its methodology.

${ }^{6} \mathrm{IE}$ scholars of this period were: Muhammad Uzair, Baqir al-Sadr, I'sa A‘bduh, Abdul Hamid Abu Sulaiman, Ḥasanuzzaman, Muḥammad Nejatullah Siddīqī, Khurshid Aḥmad, F.R. Faridi, M.A.Mannan, Aḥmad al-Shirbasi, Muḥammad al-Mubarak, Muḥammad al- Dusuqi, Yusuf al-Qaradawi, Gharib al-Jammal, Shawqi al-Fanjari, M.U.Chapra, Akram Khan, M. Anas Zarqa, Sami Ḥasan Ḥamud, Sabhuddin Zaim, Saliḥ Tug, Monzer Kahf, Muḥammad Aḥmad Saqr, Rifat al-A`wdī, A‘bd al-Salam al-Misrīi, A`bd al-Salam al- A`bbadī, A‘bd al-Samī al-Mișrī, A'bd a-Raḥman Yousrī, Masudul Alam Choudhury, etc..

${ }^{7}$ Prominent second-generation pioneers are Zubair Hasan, Salamah A‘bidīn, Ausaf Ahmad, Tag el-Dīn Seif el-Dīn, Ḥasan A‘bd-Allah al-Amīn, Shawqī Dunya, M. Fahim Khan, Munawar Iqbal, Muḥammad A‘bdul Ḥalīm U‘mar, Mohamed Aslam Haneef, etc.. 
Omercic| Integration of Knowledge (IoK) Methodological Reasoning of Islamic Economics (IE) as the Wisdom of Humanity: A Heterodox Economic Approach

Apparently, IE is of a dynamic and multidisciplinary character and so relates to socio-political and governance affairs (Asutay, 2007, 2012). Its link with religious affairs is most reflective in the requirement of Shari'ah compliance within the IBF industry as corroborated by findings of IE being rooted in Islamic jurisprudence (fiqh) and principles of Islamic jurisprudence (usul al-fiqh) (Furqani, 2015, 2017). To our knowledge based on research so far, no earlier study attempted directly and systematically to overcome problems of mainstream economics through use of IOK and IE contributions accumulatively and particularly via the recent emphasis and this paper's revived loK methodological reasoning approach. However, extant HE development can be integrated and used within IE as our appraised holistic HE approach. Thus, (1) the general stagnation of IE development because of weaker methodological foundations or an inadequate systematic understanding can be complemented through extant $\mathrm{HE}$ attempts in relation to economic orthodoxy, and (2) application of extant methodological contributions in relation to ontological, epistemological, and axiological foundations, makes this paper's preliminary systematic linking and appraisal of (1) IOK and (2) the new shift to loK methodological reasoning as the learning from each other the wisdom of humanity with IE development extensively commendable. This represents it as a holistic HE approach. It is also, after all, an accumulation of Muslim responses to incursion of Western thought and that of economics particularly. Contributions of HE as well as conventional economics help us to seriously address many issues within IE like the methodology and develop a genuine loK methodological reasoning within IE based on sound foundations that is practical and can be validated in terms of its theoretical objectives. This will enable us to pursue a more extensive development of IE. Hereby, we can bypass the current frontiers in IE development and overcome issues and foundational problems of mainstream economics along with those of other (heterodox) alternatives, IBF and easily draft plans to attain SDGs. Such issues and foundational problems were clearly our motivation and rationale in this paper and as such we showed how it can be overcome through further studies. Hence, the need to systematically review the trend of IE development in relation to the somehow newly revived loK methodological reasoning upon legacy/classical and modern bodies of knowledge. Thus, it is only after an IE firmly consolidates through such reasoning that it can overcome any problem and face any challenge. Greater emphasis on applied methodological procedures, their validation criteria and theory appraisal should be the focus in future research if willing to develop a genuine IE that in light of its multidisciplinary nature facilitates development of even other disciplines and overcoming of its challenges, issues. It is these envisioned outcomes that would reflect the real spirit of loK methodological reasoning within IE as the learning from each other and the wisdom of humanity. 
Omercic| Integration of Knowledge (IoK) Methodological Reasoning of Islamic Economics (IE) as the Wisdom of Humanity: A Heterodox Economic Approach

\section{Conclusion and Recommendation}

\subsection{Conclusion}

The need to learn from each other and integrate knowledge revealed the historical significance of exchanging the wisdom of humanity attained through accumulating knowledge of other civilisations. It promises a sustainable and harmonious life. For the Islamic civilisation, the ontological, epistemological, axiological, and methodological foundations always guided such learning from the wisdom of humanity. Such practice ended with the revival of the West and the development of mainstream economics in particular. It neutralised the morality and ethics of the Islamic civilisation in pursuit of secularisation and scientific paradigm.

The dichotomisation of economics rendered axiological questions futile while ontology and epistemology gained a purely material and rational character. The rise of the Protestant ethic shed hope for some link of economic capitalist development embedded with Christian ethical teachings while the later success of capitalism set a final blow to ethics in the name of science and its replication in mainstream economics. Heterodox economic alternatives countered the hegemonic mainstream economics because of apparent issues in theory and practice yet never addressed its foundational problems. Those revealed gaps could be addressed through the Muslim responses in the form of ișlah and tajdid movements and alternatives to mainstream economics. We identified outstanding intellectual movements and responses of IOK and IE as a holistic HE approach with genuine foundations and potential to overcome problems of mainstream economics. Thus, future studies may further systematic reviews of IOK development and IE with focus on the IoK methodological reasoning in the $21^{\text {st }}$ century which utilises extant contributions of conventional economics, HE or those of other disciplines. This is the future trajectory of IE development and genuine solution to problems and issues caused by mainstream economics, but even IBF. Moreover, attainment of SDGs could be planned and executed more efficiently and the theory of maqașid would greatly facilitate it.

Therefore, the potential welfare impact of the development of IE via loK methodological reasoning based on IOK will attempt to show how a proposed alternative integrative methodology with common ontological, epistemological and axiological foundations can then produce a holistic HE which utilises extant beneficial economic and other bodies of knowledge and become mainstream. It is best to perceive our appraised IE as a holistic HE approach to be a blueprint subject to improvement in future research. Likewise, it can be indirectly viewed as an imaginary framework of reviving loK methodological reasoning as the learning from each other the wisdom of 
Omercic| Integration of Knowledge (IoK) Methodological Reasoning of Islamic Economics (IE) as the Wisdom of Humanity: A Heterodox Economic Approach

humanity through and for IE development. It is solid ground for much actionable thought to come.

\subsection{Recommendations}

Contemporary times reveal ever greater disruptive, innovative and creative yet sound and genuine ideas, products and practice. It became harder than ever to lightly discard or ignore anything without critical insight into the potential, scalability and impact it may have. All of it has extensive economic implications. However, we witness that humanity increasingly cares about psychological, social, political, religious environmental and other implications in the $21^{\text {st }}$ century as well. Thus, a potentially disruptive, sound and genuine alternative to mainstream economics like IE with its IOK methodological reasoning becomes irresistible and greatly appeals to almost 2 billion Muslims globally. The number becomes larger if including the rising non-Muslim conversion to Islam. It has extensive implications on aspects of human life. Hence, the IE alternative and the loK methodological reasoning appraised in this paper imply certain recommendations that we consider crucial for practitioners and academics.

We recommend academics to improve the mutual communication and sharing of ideas on IE like the ones presented in this paper. Much of the research among academics remains uncommunicated and infrequently read. Increased communication of ideas to the public, practitioners and academic colleagues would raise awareness about the alternative IE to extant economic thought, services and practice. Moreover, academics should focus to elaborate how an IE approach has wide implications on general welfare. Academics could challenge the findings of papers like this and test the viability and impact of an loK methodological reasoning framework of IE on the IBF industry and attainment of SDGs. This brings us to recommendations for practitioners.

Since practitioners identified the SDGs based on exacerbated human and planetary circumstances, we recommend a shift in mainstream economic reasoning that led to such circumstances towards alternatives like IE's IoK methodological reasoning. Involving and integrating the efforts of academics based on earlier recommendations with practitioners' SDGs plans could demonstrate how IE based solutions in more stable Muslim majority nations like Malaysia, Turkey, Indonesia can impact socio-economic-political and environmental welfare. We recommend practitioners to adopt greater theoretical 'what should' solutions rather than 'what is' solutions because the later may be incongruent with the human aspirations for greater welfare and sustainability. Thus, it is not enough to comply with 'what is' even if it is 
Omercic| Integration of Knowledge (IoK) Methodological Reasoning of Islamic Economics (IE) as the Wisdom of Humanity: A Heterodox Economic Approach

welfare-enriching because the 'what should' promises greater welfare. Nonetheless, one should not be totally diverted into 'what should' without recourse to 'what is'. The two have certainly complementary implications.

Therefore, we can say that IE development through IoK methodological reasoning as the learning from each other the wisdom of humanity becomes increasingly the new 'what is' while simultaneously demonstrating the 'what should'. This paper showed how it can be done and advises future researchers to pursue greater applied and testable loK methodological reasoning-based challenges in IBF or SDGs and contribute to IE development. 
Omercic| Integration of Knowledge (IoK) Methodological Reasoning of Islamic Economics (IE) as the Wisdom of Humanity: A Heterodox Economic Approach

\section{References}

Abu Sulayman, A. (1989). Islamization of knowledge: General principles and work plan. Herndon: International Institute of Islamic Thought (IIIT).

Abu Sulayman, A. (2016). Crisis in the Muslim mind. Herndon: International Institute of Islamic Thought (IIIT).

Açikgenç, A. (2014). Islamic scientific tradition in history. Kuala Lumpur: Penerbit IKIM.

Alatas, S. F. (2014). Applying Ibn Khaldūn: The recovery of a lost tradition in sociology. New York: Routledge.

Al-Attas, M. N. (1978). Is/ām and secularism. Kuala Lumpur: Muslim Youth Movement of Malaysia.

Al-Attas, M. N. (1980). The concept of education in Islam. Kuala Lumpur: Muslim Youth Movement of Malaysia.

Al-Attas, S. M. N. (2014). Prolegomena to the metaphysics of Islam. Kuala Lumpur: Penerbit UTM Press.

Al-Faruqi, I. R. (1982). Islamization of knowledge: The problem, principles and the workplan. Herndon: International Institute of Islamic Thought (IIIT).

Argyrous, G., \& Stilwell, F. J. (Eds.). (2011). Readings in political economy: Economics as a social science. Melbourne: Tilde University Press.

Arif, M. (1985). Toward a definition of Islamic economics: Some scientific considerations. Journal of King Abdulaziz University: Islamic Economics, 2(2).

Arif, M. (1987). The Islamization of knowledge and some methodological issues in paradigm building: The general case of social science with a special focus on economics. American Journal of Islamic Social Sciences (AJISS), 4(1), 51.

Association of Heterodox Economics (2020). Association of HE. Retrieved https://www.hetecon.net/about-the-ahe/what-is-the-ahe/

Asutay, M. (2007). A political economy approach to Islamic economics: Systemic understanding for an alternative economic system. Kyoto bulletin of Islamic area studies, 1(2), 3-18.

Asutay, M. (2012). Conceptualizing and locating the social failure of Islamic finance: Aspirations of Islamic moral economy vs the realities of Islamic finance. Asian and African area studies, 11(2), 93-113.

Ayub, M. (2009). Understanding Islamic finance (Vol. 462). London: John Wiley \& Sons. 
Omercic| Integration of Knowledge (IoK) Methodological Reasoning of Islamic Economics (IE) as the Wisdom of Humanity: A Heterodox Economic Approach

Bakar, O. (1991). Tawhid and Science: Essays on the history and philosophy of Islamic science. Penang: Secretariat for Islamic Philosophy and Science.

Bakar, O. (1999). The history and philosophy of Islamic science. Cambridge: Islamic Texts Society.

Bakar, O. (2019). Classification of knowledge in Islam. Kuala Lumpur: Islamic Book Trust.

Boland, L. (2003). Foundations of economic method: A Popperian perspective. New York: Routledge.

Borella, J. (1992). René Guénon and the traditionalist school: Modern esoteric spirituality. A Cura di A. Faivre, J. Needleman, 330-358.

Carson, R. B., Thomas, W. L., \& Hecht, J. (2005). Economic issues today: Alternative approaches. New York: ME Sharpe.

Chapra, M. U. (1996). What is Islamic economics? (Vol. 9). Riyad: Islamic Development Bank (IDB), Islamic Research and Training Institute (IRTI).

Chapra, M. U. (2001). Islamic economic thought and the new global economy. Islamic Economic Studies, 9(1).

Chapra, M. U. (2016). The future of economics: An Islamic perspective. Leicester: Islamic Foundation.

Çizakça, M. (1998). Awqaf in history and its implications for modern Islamic economies. Islamic Economic Studies, 6(1).

Çizakça, M. (2000). A history of philanthropic foundations: The Islamic world from the seventh century to the present (p. 2-10). Istanbul: Boğaziçi University Press.

Crone, P. (2014). Medieval Islamic political thought. Edinburgh: Edinburgh University Press.

Crow, K. D. (2018). The intellect Islamic thought: Mind and heart. KATHA, 2(1), $1-22$.

Davis, J. B. (2008). The nature of Heterodox Economics. In Ontology and Economics (pp. 95-104). London: Routledge.

Denzin, N. K., \& Lincoln, Y. S. (2008). Collecting and interpreting qualitative materials (Vol. 3). California: Thousand Oaks, SAGE Publications.

El-Ashker, A., \& Wilson, R. (2006). Islamic economics: A short history. Leiden: Brill.

Enayat, H. (2005). Modern Islamic political thought. Kuala Lumpur: IB Tauris.

Frieden, J. A., \& Lake, D. A. (2000). International political economy. Perspectives on global power and wealth, 4. 
Omercic| Integration of Knowledge (IoK) Methodological Reasoning of Islamic Economics (IE) as the Wisdom of Humanity: A Heterodox Economic Approach

Froyen, R. T. (1996). The evolution of macroeconomic theory and implications for teaching intermediate macroeconomics. The Journal of Economic Education, 27(2), 108-115.

Froyen, R. T. (2009). Macroeconomics: Theories and policies. New York: Prentice Hall.

Fullbrook, E. (2002). The post-autistic economics movement: A brief history. Journal of Australian Political Economy, (50), 14.

Furqani, H. \& Haneef, M. A. M. (2012). Theory appraisal in Islamic economic methodology: Purposes and criteria. Humanomics, 28(4), $270-284$.

Furqani, H. (2012). The Foundations of Islamic Economics: A Philosophical Exploration of the Discipline (Doctoral dissertation). Department of Economics, Kulliyyah of Economics and Management Sciences (KNMS), International Islamic University Malaysia (IIUM), Kuala Lumpur, Malaysia.

Furqani, H. (2015). Individual and society in an Islamic ethical framework: Exploring key terminologies and the micro-foundations of Islamic economics. Humanomics, Vol. 31 Issue: 1, 74-87.

Furqani, H. (2017). Consumption and morality: Principles and behavioral

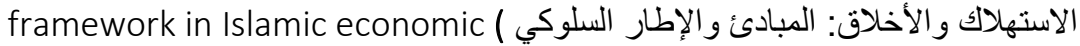
(في الاقتصاد الإسلامي (ف) Journal of King Abdulaziz University: Islamic Economics (JKAU), 30 (SI102-89).

Ghazanfar, S. M. (2003). Medieval Islamic thought: Filling the "great gap" in European economics. London: Routledge.

Hadzic, F. (2005). Islamsko bankarstvo i ekonomski razvoj. (Islamic banking and economic development). Sarajevo: Ekonomski Fakultet, Univerzitet u Sarajevu (Faculty of Economics, University of Sarajevo).

Haneef, M. A. M. (1995). Contemporary Islamic economic thought: A selected comparative analysis. Kuala Lumpur: S. Abdul Majeed \& Co.

Haneef, M. A. M. (1997). Islam, the Islamic worldview and Islamic economics. IIUM Journal of Economics and Management, 5(1), 39-66.

Haneef, M. A. M. (2005). Can there be an economics based on religion? The case of Islamic economics. Post-Autistic Economics Review, 34(3).

Haneef, M. A. M. (2014). A critical survey of Islamization of knowledge. Kuala Lumpur: IIUM Press.

Hashim, R., \& Rossidy, I. (2000). Islamization of knowledge: A comparative analysis of the conceptions of Al-Attas and Al-Faruqi. Intellectual Discourse, 8, 19-44.

Heilbroner, R. L., \& Milberg, W. S. (1995). The crisis of vision in modern economic thought. Cambridge: Cambridge University Press. 
Omercic| Integration of Knowledge (IoK) Methodological Reasoning of Islamic Economics (IE) as the Wisdom of Humanity: A Heterodox Economic Approach

Hunt, E. K. (2016). Property and Prophets: The evolution of economic institutions and ideologies: The evolution of economic institutions and ideologies. New York: Routledge.

International Institute of Islamic Thought (2020). IIIT Publications. Retrieved from https://iiit.org/en/publications-translations/

International Institute of Islamic Thought (2020a). About IIIT. Retrieved from https://iiit.org/en/about-us/

Irfan, H. (2015). Heaven's Bankers: Inside the Hidden World of Islamic Finance. New York: Abrams.

Islahi, A. A. (2005). Contribution of Muslim scholars to economic thought and analysis. Jeddah: Scientific Publisher Center, King Abdul Aziz University.

Islahi, A. A. (2010). Four generations of Islamic economists. Islamic Economics, 23(1).

Islahi, A. A. (2014). History of Islamic economic thought: Contributions of Muslim scholars to economic thought and analysis. Northampton: Edward Elgar Publishing.

Kahf, M. (1989). Islamic economics and its methodology in Readings in the Concept and Methodology of Islamic Economics. Selangor: Selangor Darul Ehsan Pelanduk Publications.

Kahf, M. (1998). Lessons in Islamic economics. Seminar Proceedings No (Vol. 41).

Kamali, M. H. (2008). Civilisational renewal: Revisiting the Islam hadhari approach: Definition, significance, criticism, recognition, support, tajdid and future directions. Kuala Lumpur: Arah Pendidikan Sdn Bhd.

Kamali, M. H. (2013). Tajdid, Islah, and Civilisational Renewal in Islam. Islam and Civilisational Renewal (ICR), 4(4).

Karčić, F. (1990). Društveno-pravni aspekti islamskog reformizma (Socio-legal aspects of Islamic reform). Sarajevo: Islamski Teoloski Fakultet (ITF) (Islamic Theology Faculty).

Kashani, M. (2014). Seekers of sacred knowledge: Zaytuna college and the education of American Muslims (Doctoral dissertation, University of Texas, Texas, United States of America (USA)). Retrieved from: https://repositories.lib.utexas.edu/bitstream/handle/2152/32815/KA SHANI-DISSERTATION-2014. pdf?sequence $=1 \&$ isAllowed $=\mathrm{y}$

Keen, S. (2011). Debunking economics: the naked emperor dethroned? London: Zed Books Ltd.

Khan, M. A. (2013). What is wrong with Islamic economics? Analyzing the present state and future agenda. London: Edward Elgar Publishing. 
Omercic| Integration of Knowledge (IoK) Methodological Reasoning of Islamic Economics (IE) as the Wisdom of Humanity: A Heterodox Economic Approach

Khan, M. F. (2013a). Theorizing Islamic economics: Search for a framework for Islamic economic analysis. Journal of King Abdul Aziz (JKAU): Islamic Economics (IE), Vol. 26, No. 1.

Koehler, B. (2014). Early Islam and the birth of capitalism. London: Lexington Books.

Kuhn, T. S. (2012). The structure of scientific revolutions. Chicago: University of Chicago press.

Lee, F. (2009). A history of HE: challenging the mainstream in the twentieth century. London: Routledge.

Lee, F. (2011). The Pluralism Debate in HE. Review of Radical Political Economics, 43, 540-51.

Lee, F. S., \& Lavoie, M. (Eds.). (2013). In defense of post-Keynesian and HE: Responses to their critics. New York: Routledge.

Mahomedy, A. C. (2016). The disintegrating force of rationalism on economics: What it means for Islamic economics (No. 611). Economic Research Southern Africa (ERSA). Durban: National Treasury of South Africa.

Mahomedy, A. C. (2017). Why the rationalist foundations of modern science are unsuitable for Islamic economics (Doctoral dissertation). Department of Accounting, Economics and Finance, College of Law and Management, University of KwaZulu-Natal, Durban, South Africa.

Malkawi, F. H. (2014). Epistemological integration: Essentials of an Islamic methodology. Herndon: International Institute of Islamic Thought (IIIT).

Mirakhor, A. (2020). Comments on the theme: "Failure of extreme capitalism Is Islamic economics the answer?". Institute Kefahamatan Islam Malaysia (IKIM). IKIM National Colloquium Series on Islamic Understanding. Kuala Lumpur: IKIM.

Mohamad, Y. (2016). Contemporary ljtihad: An Analysis of Individual and Collective Approaches. Selangor: ISSI dan YADIM.

Nașr, H. S. (1996). Religion and the order of nature (No. 167). Oxford: Oxford University Press on Demand.

Nasr, H. S. (2006). Islamic philosophy from its origin to the present: Philosophy in the land of Prophecy. New York: State University of New York Press.

Nasr, S. H. (2006a). Spirituality and science: Convergence or divergence. The Essential Sophia, 214.

Nasr, S. H. (2010). Islam in the modern world: Challenged by the west, threatened by fundamentalism, keeping faith with tradition. New York: HarperOne.

Oatley, T. (2015). International political economy. London: Routledge. 
Omercic| Integration of Knowledge (IoK) Methodological Reasoning of Islamic Economics (IE) as the Wisdom of Humanity: A Heterodox Economic Approach

Omercic, J. (2018). Socio-economic Potential of Waqf in Bosnia and Herzegovina. Sarajevo: Centar za Napredne Studije (CNS).

Omercic, J. (2021). Economic Thought at the Crossroads: Developing a Framework of Islamic Economics Through Integration of Knowledge. (Doctoral dissertation). Department of Economics, Kulliyyah of Economics and Management Sciences (KNMS), International Islamic University Malaysia (IIUM), Kuala Lumpur, Malaysia.

Omercic, J., Haneef, M. A. M., \& Mohammed, M. O. (2020). Economic Thought, Foundational Problems of Mainstream Economics and the Alternative of Islamic Economics. International Journal of Islamic Economics and Finance (IJIEF), 3(2), 171-198.

Ormerod, P., Camerer, C. F. L., George Rabin, M., Case, K. E., Samuelson, P. A., Heilbroner, R. L., \& Boulding, K. E. (1997). The death of economics. New York: Russell Sage Foundation.

Piketty, T. (2014). Capital in the 21st Century. Massachusetts: Belknap Press of Harvard University Press.

Post-Autistic Economics Network, (2020). Post-Autistic Economics. Retrieved from http://www.paecon.net/HistoryPAE.htm

Power, M. (2012). A history of HE. On The Horizon-The Strategic Planning Resource for Education Professionals, 20(3), 253-259.

Pribram, K. (1983). A history of economic reasoning (p. 209). Baltimore: Johns Hopkins University Press.

Putnam, H., \& Walsh, V. (Eds.). (2012). The end of value-free economics. New York: Routledge.

Ritchie, J., \& Lewis, J. (2003). Qualitative Research Practice: A guide for Social Science Students Researchers. London: SAGE Publications.

Sadr, M. B. (1982). Our Economics (English Translation), Vol. 1, Part 2. Tehran: World Organization for Islamic Services.

Sadr, M. B. (1982). Our Economics (English Translation), Vol. 1, Part 1. Tehran: World Organization for Islamic Services.

Sadr, M. B. (1982). Our Economics (English Translation), Vol. 2, Part 2. Tehran: World Organization for Islamic Services.

Sadr, M. B. (1982). Our Economics (English Translation), Vol. 2, Part 1. Tehran: World Organization for Islamic Services.

Sadr, M. B. (1987). Our philosophy. Trans. Sham SC Inati. London: Muhammadi Trust.

Sadr, S. K. (2016). The Economic system of the early Islamic period: Institutions and policies. New York: Palgrave Macmillan. 
Omercic| Integration of Knowledge (IoK) Methodological Reasoning of Islamic Economics (IE) as the Wisdom of Humanity: A Heterodox Economic Approach

Safi, L. (1993). The quest for Islamic methodology: The Islamization of knowledge project in its second decade. American Journal of Islamic Social Sciences (AJISS), 10(1), 23.

Said, E. W. (1979). Orientalism. New York: Vintage.

Saliba, G. (2007). Islamic science and the making of the European Renaissance. Massachusetts: MIT Press.

Samuels, W. J., Biddle, J. E., \& Davis, J. B. (Eds.). (2008). A companion to the history of economic thought. Malden: John Wiley \& Sons.

Sardar, Z. \& Henzell-Thomas J. (2017). 'Rethinking reform in higher education: From Islamization to integration of knowledge'. Herndon: International Institute of Islamic Thought (IIIT).

Sardar, Z. (1989). Islamization of Knowledge: A state of the art report. An early crescent: The future of knowledge and the environment in Islam, 2756.

Schumpeter, J. A. (1954). History of economic analysis. London: EB Schumpeter.

Schuon, F. (2005). The Essential Frithjof Schuon. Indiana: World Wisdom, Inc.

Screpanti, E., \& Zamagni, S. (2005). An outline of the history of economic thought. Oxford: Oxford University Press on Demand.

Shamsul, A. B. (1997). Identity construction, nation formation, and Islamic revivalism in Malaysia. Islam in an era of nation-states: Politics and religious renewal in Muslim Southeast Asia, 207-227.

Shiller, R. J. (2015). Irrational exuberance: Revised and expanded third edition. Princeton: Princeton University Press.

Siddiqi, M. N. (1981). Muslim economic thinking: a survey of contemporary literature (Vol. 1). Riyadh: International Centre for Research in Islamic Economics, King Abdul Aziz University.

Siddiqi, M. N. (1983). Issues in Islamic Banking. J. Res. Islamic Econ., 1(1), 5759.

Siddiqi, M. N. (2004). Islamic economics: Current state of knowledge and development of the discipline. Round Table on Islamic Economics, 2627.

Siddiqi, M. N. (2004a). Riba, bank interest and the rationale of its prohibition. Jeddah: Islamic Research and Training Institute.

Stiglitz, J. E. (2010). Freefall: America, free markets, and the sinking of the world economy. New York: WW Norton \& Company.

Stiglitz, J. E. (2019). People, power, and profits: Progressive capitalism for an age of discontent. New York: WW Norton \& Company. 
Omercic| Integration of Knowledge (IoK) Methodological Reasoning of Islamic Economics (IE) as the Wisdom of Humanity: A Heterodox Economic Approach

Toynbee, A. J. (1987). A Study of History: Volume I: Abridgement of Volumes IVI (Vol. 1). Oxford: Oxford Paperbacks.

Voll, J. O. (1983). Renewal and reform in Islamic history: Tajdid and islah. Voices of Resurgent Islam, 32-47.

Wain, A. \& Kamali, M. H. (2018). The architects of Islamic civilization. Kuala Lumpur: Institute for Advanced Islamic Studies (IAIS).

Wan Daud, M. N. (1998). The educational philosophy and practice of Syed Muhammad Naquib al-Attas: An exposition of the original concept of Islamization. Kuala Lumpur: International Institute of Islamic Thought and Civilization (ISTAC) Press.

Wan Daud, M.N. (2010). Knowledge, language, thought, and the civilization of Islam: Essays in honor of Syed Muhammad Naquib Al-Attas. Kuala Lumpur: Penerbit UTM Press.

Weber, M. (2002). The Protestant ethic and the spirit of capitalism and other writings. New York: Penguin.

Weiss, D. (1995). Ibn Khaldun on economic transformation. International Journal of Middle East Studies, 27(1), 29-37.

Zaman, A. (2010). Islamic economics: A survey of the literature. Islamic Studies, 49(1), 37-63.

Zaman, A. (2013). Logical positivism and Islamic economics. International Journal of Economics, Management and Accounting, 21(2). 